\title{
PENINGKATAN PRESTASI BELAJAR PKn MELALUI PENERAPAN \\ METODE PEMBELAJARAN FRIEND GIVING SISWA KELAS IX-A SMP NEGERI 1WONOASRI MADIUN \\ TAHUN PELAJARAN 2014/2015
}

\author{
Sukarsi*
}

\begin{abstract}
Abstrak
Denelitian ini bertujuan untuk mengetahui metode pembelajaran friend giving yang dapat mengoptimalkan minat dan hasil belajar siswa terhadap mata pelajaranPKn. Penelitian dilaksanakan di kelas IX A SMP Negeri 1 Wonoasri Madiun. Jenis penelitian ini adalah Penelitian Tindakan Kelas dengan 4 langkah tindakan, yaitu; (1) rencana tindakan, (2) pelaksanaan tindakan, (3) observasi, dan (4) refleksi. Teknik analisis data yang penulis gunakan adalah menggunakan nilai rata-rata dan prosentase ketuntasan belajar. Hasil analisis data menunjukkan bahwa ada peningkatan nilai pada setiap siklus. Siklus I dengan nilai rata-rata 69,62 menjadi 79,42 pada siklus 2. Selain itu, metode pembelajaran friend giving menjadikan siswa lebih aktif dan meningkatkan minat mempelajari PKn.
\end{abstract}

Kata Kunci: Prestasi Belajar, Metode Fiend Giving

\footnotetext{
* Mahasiswa Prodi PPKn IKIP PGRI Madiun
} 
PENDAHULUAN

Tantangan

terhadap

peningkatan mutu, relevansi, dan

efektivitas pendidikan sebagai

tuntutan nasional sejalan dengan

perkembangan dan kemajuan

masyarakat, berimplikasi secara

nyata dalam program pendidikan dan

kurikulum sekolah. Tujuan dari

program kurikulum dapat tercapai

dengan baik jika programnya

didesain secara jelas dan aplikatif.

Dalam hubungan inilah, para guru

dituntut untuk memiliki kemampuan

mendesain programnya dan sekaligus

menentukan strategi instruksional

yang harus ditempuh."Para guru

harus memiliki ketrampilan memilih

dan menggunakan metode mengajar

untuk diterapkan dalam sistem pembelajaran yang efektif"

(Hamalik, 2001:26). Oleh karena itu, guru dipandang sebagai agen modernisasi dalam segala bidang. Usaha utama yang dapat dilakukan oleh guru melalui program pendidikan bagi para siswa. Dalam melakukan usaha pencapaian tujuan pendidikan di sekolah tersebut, guru berperan penting dalam menggunakan metode dan cara untuk mencapai hasil belajar yang optimal.
Untuk mencapai tujuan tersebut sangat didukung oleh strategi yang digunakan guru dalam proses belajar mengajar.

Usman

(2002:144)

mengatakan bahwa proses belajar mengajar merupakan suatu proses yang mengandung serangkaian perbuatan guru dan siswa atas dasar hubungan timbal balik yang berlangsung dalam situasi edukatif untuk mencapai tujuan tertentu. Interaksi dan hubungan timbal balik antara guru dan siswa itu merupakan syarat utama bagi berlangsungnya proses belajar mengajar. Berdasarkan pendapat tersebut, Kusaeri (2001:96), mengatakan bahwa guru sebagai pelaksana terdepan, harus dapat mengantisipasi perkembangan ini dengan memberikan materi pembelajaran dengan strategi pengajaran yang diinginkan oleh siswa sehingga materi yang dipelajari akan dapat diterima dengan baik oleh siswa dan guru dapat memberikan dengan baik pula. Hal ini akan dapat terlaksana apabila guru dapat menyesuaikan dengan perkembangan zaman dalam menyampaikan materi dengan strategi belajar yang dapat meningkatkan kreativitas siswa juga. 
Jika tidak diimbangi dengan pengetahuan guru yang baik, tidak menutup kemungkinan bahwa pengetahuan guru akan kalah dan tertinggal dari pengetahuan siswa. Artinya, dengan menggunakan strategi pembelajaran yang benar akan mengarahkan siswa pada ketercapaian tujuan pendidikan yang dirumuskan.

Dalam pembelajaran Pendidikan Kewarganegaraan(PKn) untuk siswa kelas IX A SMP Negeri 1 Wonoasri Madiun tahun pelajaran 2014/2015 masih ditemukan kurangnya partisipasi siswa dalam mengikuti pembelajaran. Guru cenderung aktif sedangkan siswanya pasif. Hal ini disebabkan oleh guru lebih senang menggunakan strategi pembelajaran konvensional seperti menerangkan materi sehingga siswa bosan. Kondisi ini menyebabkan prestasi belajar siswa sangat rendah.

Dewasa ini telah dikembangkan suatu pendekatan pembelajaran kooperatif untuk menghasilkan tujuan belajar yang baik. Mengapa harus kooperatif ? Menurut Nurhadi (2002: 32) "sejauh ini pendidikan di Indonesia masih didominasi oleh pandangan bahwa pengetahuan sebagai perangkat fakta-fakta yang harus dihafal". Kelas masih berfokus pada guru sebagai sumber utama pengetahuan yang menjadikan ceramah adalah pilihan utama strategi belajar. Untuk itu, diperlukan sebuah strategi baru yang lebih memberdayakan siswa. Sebuah strategi belajar yang tidak mengharuskan siswa menghafal fakta-fakta tetapi sebuah strategi yang mendorong siswa mengkonstruksikan pengetahuan di pikiran mereka.

Kenyataan di lapangan, proses pencapaian pembelajaran di SMP Negeri 1 Wonoasri Madiun masih menggunakan paradigma lama walaupun sekarang kurikulum telah berkembang menuju Kurikulum Berbasis KTSP. Tidak menutup kemungkinan hasil belajar yang dicapai oleh siswapun terkesan monoton karena hanya menghapal suatu fakta dan guru dipandang sebagai sumber utama dalam belajar. Salah satu hasil belajar yang diperoleh adalah mata pelajaran PKn untuk kelas IX A menunjukkan hasil yang belum memenuhi ketuntasan secara klasikal. Untuk mata pelajaran PKn SMP Negeri 1 Wonoasri 
Madiun menetapkan KKM sebesar 70. Suatu kelas dinyatakan tuntas secara klasikal apabila jumlah siswa yang telah tuntas belajar secara individu mencapai $\geq 85 \%$.

$$
\text { Berdasarkan beberapa }
$$

pendapat di atas, diambil kesimpulan bahwa guru harus memiliki keterampilan dalam menggunakan metode pembelajaran pada setiap proses belajar mengajar dan strategi pengajaran yang tepat. Dari kenyataan tersebut, dilakukan suatu penelitian tindakan kelas dengan melakukan perubahan strategi belajar mengajar mata pelajaran PKn pada siswa kelas IX A SMP Negeri 1 Wonoasri Madiun tahun pelajaran 2014/2015 dengan menggunakan metode pembelajaran Friend Giving.

\section{METODE PENELITIAN}

Penelitian ini dilaksanakan di kelas IX A SMP Negeri 1 Wonoasri Madiun. Untuk memperlancar kegiatan penelitian ini, dilakukan persiapan sebagai berikut:1) Melakukan koordinasi dengan kepala sekolah, guru mata pelajaran sejenis sebagai bentuk kolaborasi. 2) Menerangkan secara umum tentang indikator materi yang akan dicapai.
3) Menerangkan secara garis besar tentang materi pelajaran tentang pentingnya pembelaan negara. 4) Membagi siswa menjadi beberapa kelompok. 5) Memberi tugas kelompok tentang pentingnya pembelaan negara berikut pertanyaan kunci untuk dijawab mempresentasikan di depan kelas. 6) Menentukan rencana pekerjaan. 7)Menyediakan peralatan yang diperlukan untuk penelitian.

Jenis instrumen yang digunakan adalah lembar kompetensi siswa berupa lembar penilaian siswa, lembar observasi guru, angket, dan naskah soal. Data yang dicatat adalah wawasan siswa, kreativitas siswa, keterampilan siswa, kecerdasan visual dan bakat/potensi diri. Untuk menindaklanjuti data tersebut, digunakan analisis deskripsi, memaparkan data dari hasil pengamatan dan membandingkan hasil yang dicapai tiap siklus.

Pada Penelitian Tindakan Kelas, pelaksanaan tindakan ada 4 langkah, yaitu; 1) rencana tindakan, 2) pelaksanaan tindakan, 3) observasi, dan 4) refleksi. Pada Tahap rencana tindakan guru menyusun rencana pembelajaran 
serta intrumen tindakan yang diperlukan dalam pelaksanaan penelitian tindakan kelas. Pada tahap Pelaksanaan tindakan penelitian langkah-langkah yang dilakukan dalam metode friend giving" sebagai berikut :

1. Setiap kelompok diberi tugas dalam waktu yang sudah ditentukan tahap pertama. Tugas yang diberikan meliputi tugas tentang memecahkan masalah yang berkaitan dengan menjelaskan pentingnya pembelaan negara.

2. Semua tugas kelompok dikumpulkan untuk didiskusikan dengan kelompok laindan menilai hasil pekerjaan kelompok lain menggunakan lembar penilaian siswa.

3. Semua hasil pekerjaan siswa dipresentasikan dalam suatu ruang kelas tertentu. Guru mengadakan pengamatan/observasi dan memberi evaluasi tugas kelompok

4. Siswa diberi kesempatan untuk mempresentasikan hasil tugasnya, kemudian guru memberi refleksi dan memberi kesimpulan akhir.

Pada saat yang bersamaan guru melakukan observasi dan mengadakan penilaian teradap kinerja siswa dalam pelaksanaan pembelajaran. Hasil observasi dianalisis pada tahap refleksi untuk kemudian digunakan sebagai bahan pertimbangan pada siklus selanjutnya.

Analisis data dalam penelitian inimenggunakan nilai ratarata dan prosentase ketuntasan belajar. Agar mendapat gambaran yang jelas, teknik statistik yang digunakan dengan rumus mean (ratarata), yaitu: $M=\frac{\sum x}{N}$

Keterangan:

$$
\begin{aligned}
M= & \text { Nilai rata-rata } \\
\sum x= & \text { Jumlah nilai } \\
& \text { siswa } \\
N= & \text { Jumlah siswa }
\end{aligned}
$$

Untuk mengetahui prosentase ketuntasan belajar dengan rumus:

Jumlah siswa tuntas x 100

Jumlah seluruh siswa

\section{HASIL DAN PEMBAHASAN}

Penyajian hasil penelitian ini dapat dipaparkan dalam beberapa urutan penelitian kedalam siklussiklus. Berikut pemaparan masingmasing siklus. 
1. Siklus I

Dalam

perencanaan

penelitian tindakan kelas ini, dilakukan hal-hal sebagai berikut: Guru memberi rangkuman materi kepada siswa tentang materi PKn pada kompetensi dasar menjelaskan pentingnya pembelaan negara; kemudian guru melaksanakan pretest; guru membagi kelas dalam 4 kelompok; Guru menentukan ketua kelompok yang akan menjadi evaluator serta juru bicara dalam berdiskusi; Guru memberi tugas memahami tentang pentingnya bela negara.; Setiap kelompok mengumpulkan hasil tugasnya kemudian mendiskusikan dan menilai; Semua kelompok diberi tugas mempresentasikan hasil tugasnya; Guru melakukan observasi, memberi arahan-arahan perbaikan serta mengadakan penilaian dengan menggunakan lembar penilaian guru; Guru melakukan postest pada akhir siklus.

Tahap pelaksanaan, pada tahap ini, diuraikan secara detail tentang realisasi proses pelaksanaan pembelajaran dengan menggunakan metode friend giving. Pelaksanaan penelitian ini terbagi dalam dua siklus, yaitu seperti tertuang dalam siklus satu kemudian diulang sama persis pada siklus kedua agar diperoleh hasil yang maksimal.

Ketika siswa berdiskusi di intern kelompoknya, mempresentasikan hasil tugasnya, menanggapi dan memberikan sanggahan pada kelompok lain masih terdapat siswa yang pasif namun tingkat keaktifannya mulai ada peningkatan. Untuk mengukur kemampuan siswa dalam mendalami materi dan mengukur minat siswa, kerja sama siswa, sikap siswa terhadap proses pelaksanaan pembelajaran mata pelajaran PKn pada kompetensi dasar menjelaskan pentingnya pembelaan negara dengan metode friend giving, digunakan intrumen-instrument pretest, LPS, angket dan postest.

Tahap pengamatan dan evaluasi. pada tahap ini, guru mengadakan pengamatan dan evaluasi terhadap siswa selama proses pembelajaran berlangsung dengan hasil sebagai berikut: 
Tabel 1.Data Observasi Siklus I

Kegiatan Siswa pada

pembelajaran dengan friend

$$
\text { giving }
$$

\begin{tabular}{|c|c|c|}
\hline No & Kegiatan & Hasil \\
\hline 1. & $\begin{array}{l}\text { Antusias siswa dalam } \\
\text { mengikuti jalannya } \\
\text { proses pembelajaran }\end{array}$ & Baik \\
\hline 2. & $\begin{array}{l}\text { Antusias siswa dalam } \\
\text { melaksanakan tugas } \\
\text { kelompok sesuai dengan } \\
\text { materi yang diperoleh }\end{array}$ & Cukup \\
\hline 3. & $\begin{array}{lll}\text { Antusias siswa } & \text { dalam } \\
\text { mengikuti } & \text { KBM } & \text { dengan } \\
\text { menggunakan } & \text { Friend } \\
\text { Giving } & \end{array}$ & Cukup \\
\hline 4. & $\begin{array}{lr}\text { Ekspresi siswa } & \text { yang } \\
\text { mendapat } & \text { tugas, } \\
\text { utamanya } & \text { sebagai } \\
\text { evaluator dan juru bicara } & \\
\text { saat berdiskusi kelompok }\end{array}$ & Kurang \\
\hline 5. & $\begin{array}{l}\text { Keaktifan siswa di } \\
\text { masing-masing } \\
\text { kelompok saat awal } \\
\text { memehami materi }\end{array}$ & Kurang \\
\hline 6. & $\begin{array}{l}\text { Keaktifan siswa di } \\
\text { masing-masing } \\
\text { kelompok ketika KBM } \\
\text { berlangsung }\end{array}$ & Cukup \\
\hline 7. & $\begin{array}{l}\text { Keaktifan siswa di } \\
\text { masing-masing } \\
\text { kelompok saat akhir } \\
\text { KBM }\end{array}$ & Kurang \\
\hline 8. & $\begin{array}{l}\text { Tanggapan siswa } \\
\text { terhadap KBM dengan }\end{array}$ & Baik \\
\hline
\end{tabular}

\begin{tabular}{|l|l|l|}
\hline $\begin{array}{l}\text { menggunakan metode } \\
\text { Friend Giving }\end{array}$ & \\
\hline
\end{tabular}

Selain pengamatan pada siswa selama proses pembelajaran, kepada siswa juga diberikan angket untuk mengetahui pendapatnya tentang penggunaan metode friend giving dengan hasil sebagaimana tercantum pada table 2 berikut.

Tabel 2

Data Angket untuk Siswa

Siklus I

\begin{tabular}{|c|c|c|c|}
\hline \multirow{2}{*}{ No. } & \multirow{2}{*}{ Pertanyaan } & \multicolumn{2}{|c|}{ Siklus I $(\%)$} \\
\hline & & Ya & Tidak \\
\hline 1. & $\begin{array}{l}\text { Apakah pembelajaran } \\
\text { dengan metode friend } \\
\text { giving menyenangkan? }\end{array}$ & 40 & 60 \\
\hline 2. & $\begin{array}{l}\text { Apakah pembelajaran } \\
\text { denga metode friend } \\
\text { giving membuat kamu } \\
\text { mudah memahami } \\
\text { materi? }\end{array}$ & 60 & 40 \\
\hline 3. & $\begin{array}{l}\text { Apakah kamu senang } \\
\text { menjadi ketua } \\
\text { kelompok, evaluator } \\
\text { dan juru bicara saat } \\
\text { berdiskusi? }\end{array}$ & 42 & 58 \\
\hline 4. & $\begin{array}{l}\text { Apakah kamu } \\
\text { mengalami kesulitan } \\
\text { dalam menjalankan } \\
\text { tugas sebagai ketua } \\
\text { kelompok, evaluator }\end{array}$ & 36 & 64 \\
\hline
\end{tabular}




\begin{tabular}{|c|c|c|c|}
\hline & dan juru bicara? & & \\
\hline 5. & $\begin{array}{lr}\text { Apakah kamu } & \text { sudah } \\
\text { mempelajari } & \text { materi } \\
\text { yang } & \text { akan } \\
\text { didiskusikan } & \text { dengan } \\
\text { kelompok } & \end{array}$ & 50 & 50 \\
\hline 6. & $\begin{array}{l}\text { Apakah kamu merasa } \\
\text { kesulitan menerangkan } \\
\text { /mempresentasikan } \\
\text { hasil pekerjaan kamu } \\
\text { dihadapan siswa dan } \\
\text { guru? }\end{array}$ & 40 & 60 \\
\hline 7. & $\begin{array}{l}\text { Apakah kamu merasa } \\
\text { kesulitan dalam } \\
\text { mengisi lembar } \\
\text { penilaian siswa? }\end{array}$ & 45 & 55 \\
\hline 8. & $\begin{array}{lr}\text { Apakah kamu } & \text { merasa } \\
\text { kesulitan } & \text { dalam } \\
\text { mengerjakan } & \text { soal-soal } \\
\text { posttest } & \text { setelah } \\
\text { presentasi, berdiskusi } \\
\text { dan setelah } & \text { mengisi } \\
\text { lembar } & \text { penilaian } \\
\text { siswa? } & \end{array}$ & 49 & 51 \\
\hline
\end{tabular}

Selama dan setelah proses pembelajaran dengan metode friend giving, diperoleh hasil penilaian terhadap pelajaran PKn dengan hasil sebagaimana tercantum pada table 3 berikut.

Tabel 3.Hasil Penilaian Siklus I

$$
(\mathrm{SKBM}=70)
$$

\begin{tabular}{|c|l|c|c|}
\hline No. & Kriteria & jumlah & $\%$ tase \\
\hline 1. & Tuntas & 12 & 46,15 \\
\hline 2. & Remidi & 24 & 53,85 \\
\hline & & 26 & \\
\hline
\end{tabular}

Jumlah total prestasi belajar $=$ 1810 dengan rata-rata 69,62

Tahap Refleksi, setelah melihat hasil pengamatan dari tabel nilai siswa, sebelum dan sesudah siklus I berlangsung sesuai dengan ketentuan (waktu maupun tingkat ketuntasannya). Kondisi yang dapat dianalisis dari proses pelaksanaan pembelajaran dengan metode pembelajaran friend giving, dapat diberikan beberapa poin stressing refleksi yaitu persiapan materi, pelaksanaan pembelajaran, dan pengamatan dan evaluasi.

Dalam mempersiapkan materi untuk pelaksanaan siklus I cakupan materi banyak dan luas. Artinya,pembagian materi yang disesuaikan dengan KD masingmasing kelompok terlalu banyak sehingga menjadikan kesulitan tersendiri bagi siswa untuk memahaminya dalam waktu relatif singkat. Untuk guru PKn perlu memperhatikan hal ini pada pelaksanaan siklus berikutnya. 
Dalam pelaksanaan KBM, siswa dibagi menjadi 4 kelompok yang ditentukan oleh guru. Adapun pembagian kelompok ini kurang memperhatikan tingkat kemampuan, keaktifan, sikap dari masing-masing siswa, sehingga dalam proses KBM dijumpai kelompok yang aktif dan kelompok yang pasif. Hal ini dapat menjadi hambatan untuk mencapai ketuntasan belajar siswa.

Dari hasil pengamatan awal siklus I yang ditinjau dari segi pemahaman materi, siswa dirasa kurang tuntas.Hal ini tampak dari nilai rata-rata siswa masih ada yang dibawah SKBM. Setelah akhir siklus I ternyata nilai ratarata siswa juga masih dibawah SKBM. Untuk mencapai kompetensi yang sesungguhnya, masih perlu pelaksanaan penelitian pada siklus berikutnya.

\section{Siklus II}

$$
\text { Dalam perencanaan }
$$
penelitian tindakan kelas ini, dilakukan hal-hal sebagai berikut: 1)Guru memberi rangkuman materi kepada siswa tentang materi PKn pada kompetensi dasar menjelaskan pentingnya pembelaan negara, 2)Guru melaksanakan pretest, 3)Guru membagi kelas dalam 4 kelompok, 4) Guru menentukan ketua kelompok yang nantinya akan menjadi evaluator serta juru bicara dalam berdiskusi, 5) Guru memberi tugas memahami tentang pentingnya pembelaan negara. 6) Setiap kelompok mengumpulkan hasil tugasnya kemudian mendiskusikan dan menilai. 7) Semua kelompok diberi tugas mempresentasikan hasil tugasnya, 8) Guru melakukan observasi, memberi arahan-arahan penyempurnaan serta mengadakan penilaian dengan menggunakan lembar penilaian guru, 9) Guru melakukan postest pada akhir siklus.

Tahap Pelaksanaan, pada tahap ini, diuraikan secara detail tentang realisasi proses pelaksanaan KBM dengan menggunakan metode friend giving. Pelaksanaan penelitian ini sama persis pada siklus pertama agar diperoleh hasil yang maksimal. 
Ketika siswa berdiskusi di intern kelompoknya, mempresentasikan hasil tugasnya, menanggapi dan memberikan sanggahan pada kelompok lain masih terdapat siswa yang pasif namun tingkat keaktifannya mulai ada peningkatan. Untuk mengukur kemampuan siswa dalam mendalami materi dan mengukur minat, kerja sama, dan sikap siswa terhadap proses pelaksanaan KBM mata pelajaran PKn pada kompetensi dasar menjelaskan pentingnya pembelaan negara dengan metode friend giving, digunakan intrumen-instrument pretest, LPS, angket dan postest.

Tahap pengamatan dan evaluasi, pada tahap ini guru mengadakan pengamatan dan evaluasi terhadap siswa selama proses pembelajaran berlangsung pada siklus dua.Hasilnya sebagai berikut:

Tabel 4. Data Observasi Siklus I

Kegiatan Siswa pada pembelajaran dengan friend giving

\begin{tabular}{|c|l|c|}
\hline No & \multicolumn{1}{|c|}{ Kegiatan } & Hasil \\
\hline 1. & $\begin{array}{l}\text { Antusias siswa dalam } \\
\text { mengikuti jalannya } \\
\text { proses pembelajaran }\end{array}$ & Baik \\
\hline
\end{tabular}

\begin{tabular}{|c|c|c|}
\hline 2. & $\begin{array}{l}\text { Antusias siswa dalam } \\
\text { melaksanakan } \\
\text { kelompok } \\
\text { materi yang diperoleh }\end{array}$ & Baik \\
\hline 3. & $\begin{array}{l}\text { Antusias siswa dalam } \\
\text { mengikuti } \mathrm{KBM} \text { dengan } \\
\text { Friend Giving }\end{array}$ & Baik \\
\hline 4. & $\begin{array}{l}\text { Ekspresi siswa yang } \\
\text { mendapat tugas, utamanya } \\
\text { sebagai evaluator dan juru } \\
\text { bicara saat berdiskusi } \\
\text { kelompok }\end{array}$ & Baik \\
\hline 5. & $\begin{array}{l}\text { Keaktifan siswa di } \\
\text { masing-masing kelompok } \\
\text { saat awal memehami } \\
\text { materi }\end{array}$ & Cukup \\
\hline 6. & $\begin{array}{l}\text { Keaktifan siswa di } \\
\text { masing-masing kelompok } \\
\text { ketika KBM berlangsung }\end{array}$ & Baik \\
\hline 7. & $\begin{array}{l}\text { Keaktifan siswa di } \\
\text { masing-masing kelompok } \\
\text { di akhir KBM }\end{array}$ & Cukup \\
\hline 8. & $\begin{array}{l}\text { Tanggapan siswa } \\
\text { terhadap KBM dengan } \\
\text { menggunakan metode } \\
\text { Friend Giving }\end{array}$ & Baik \\
\hline
\end{tabular}

Selain pengamatan pada siswa selama proses pembelajaran, kepada siswa juga diberikan angket untuk mengetahui pendapatnya tentang penggunaan metode friend giving 
dengan hasil sebagaimana tercantum pada table 5 berikut.

Tabel 5. Data Angket untuk Siswa

Siklus II

\begin{tabular}{|c|c|c|c|}
\hline \multirow{2}{*}{ No } & \multirow{2}{*}{ Pertanyaan } & \multicolumn{2}{|c|}{ Siklus II (\%) } \\
\hline & & $\mathrm{Ya}$ & Tidak \\
\hline 1. & $\begin{array}{l}\text { Apakah dengan } \\
\text { metode friend giving } \\
\text { menyenangkan? }\end{array}$ & 60 & 40 \\
\hline 2. & $\begin{array}{l}\text { Apakah dengan } \\
\text { metode friend giving } \\
\text { membuat } \\
\text { mudah memahami } \\
\text { materi? }\end{array}$ & 75 & 25 \\
\hline 3. & $\begin{array}{l}\text { Apakah kamu senang } \\
\text { menjadi ketua } \\
\text { kelompok, evaluator } \\
\text { dan juru bicara saat } \\
\text { berdiskusi? }\end{array}$ & 57 & 43 \\
\hline 4. & $\begin{array}{l}\text { Apakah kamu } \\
\text { mengalami kesulitan } \\
\text { dalam menjalankan } \\
\text { tugas sebagai ketua } \\
\text { kelompok, evaluator } \\
\text { dan juru bicara? }\end{array}$ & 68 & 32 \\
\hline 5. & $\begin{array}{lr}\text { Apakah kamu } & \text { sudah } \\
\text { mempelajari } & \text { materi } \\
\text { yang } & \text { akan } \\
\text { didiskusikan } & \text { dengan } \\
\text { kelompok } & \end{array}$ & 93 & 17 \\
\hline 6. & $\begin{array}{l}\text { Apakah kamu merasa } \\
\text { kesulitan } \\
\text { menerangkan } \\
\text { mempresentasikan }\end{array}$ & 56 & 44 \\
\hline
\end{tabular}

\begin{tabular}{|c|c|c|c|}
\hline & $\begin{array}{l}\text { hasil pekerjaan kamu } \\
\text { dihadapan siswa dan } \\
\text { guru? }\end{array}$ & & \\
\hline 7. & $\begin{array}{l}\text { Apakah kamu merasa } \\
\text { kesulitan dalam } \\
\text { mengisi lembar } \\
\text { penilaian siswa? }\end{array}$ & 69 & 31 \\
\hline 8. & $\begin{array}{l}\text { Apakah kamu merasa } \\
\text { kesulitan dalam } \\
\text { mengerjakan soal- } \\
\text { soal posttest setelah } \\
\text { presentasi, berdiskusi } \\
\text { dan setelah mengisi } \\
\text { lembar penilaian } \\
\text { siswa? }\end{array}$ & 87 & 13 \\
\hline
\end{tabular}

Tabel 6. Hasil Penilaian Siklus II $(\mathrm{SKBM}=70)$

\begin{tabular}{|c|l|c|c|}
\hline No. & Kriteria & jumlah & $\%$ tase \\
\hline 1. & Tuntas & 25 & 96,15 \\
\hline 2. & Remidi & 1 & 3,85 \\
\hline & & 26 & \\
\hline
\end{tabular}

Jumlah total prestasi belajar $=$ 2065 dengan rata-rata 79, 42

Tahap Refleksi, setelah melihat hasil pengamatan dari tabel nilai siswa, sebelum dan sesudah siklus II berlangsung sesuai dengan ketentuan (waktu maupun tingkat ketuntasannya). Kondisi yang dapat dianalisis dari proses pelaksanaan KBM dengan 
metode pembelajaran friend giving, dapat diberikan beberapa poin stressing refleksi yaitu persiapan materi, pelaksanaan pembelajaran, dan pengamatan dan evaluasi yaitu.

Dalam mempersiapkan materi untuk pelaksanaan siklus II cakupan materi telah dipersempit. Soal yang diberikan pada siswa dapat diselesaikan dengan waktu yang telah ditentukan.

Dalam pelaksanaan pembelajaran, karena dengan 4 kelompok yang beranggotakan 7 8 orang dianggap kurang efektif, pada siklus II dijadikan menjadi 7 kelompok yang beranggotakan 45 orang. Pembagian kelompok telah disesuaikan dengan hasil tes siklus kedua.

Dalam pengamatan dan evaluasi, dari hasil pengamatan awal siklus II yang ditinjau dari segi pemahaman materi siswa dirasa sudah cukup baik dan telah mengalami peningkatan dari kegiatan pada siklus II.

Berdasarkan hasil pengamatan dan analisis, selanjutnya dicatat dalam instrumen-instrumen penilaian.
Dimulai dari siklus I, kegiatan siswa pada saat KBM dengan metode pembelajaran Friend Giving, antusias siswa secara umum baik namun siswa yang mendapat tugas sebagai juru bicara kelompok masih merasa terbebani sehingga ekspresi siswa tersebut kurang baik, keaktifan siswa di intrern kelompok cukup, bahkan cenderung pasif.

Untuk memberi gambaran maka disajikan perbandingan dari hasil kedua siklus tersebut sebagai berikut:

Tabel 7. Perbandingan prestasi belajar PKn Siklus I dan II

\begin{tabular}{|l|c|c|}
\hline & Siklus 1 & Siklus 2 \\
\hline Jumlah & 1810 & 2065 \\
\hline Rata-rata & 69.62 & 79.42 \\
\hline Prosentase tuntas & $53.85 \%$ & $96,15 \%$ \\
\hline
\end{tabular}

Diagram rata-rata nilai dan ketuntasan belajar dapat dilihat sebagai berikut:

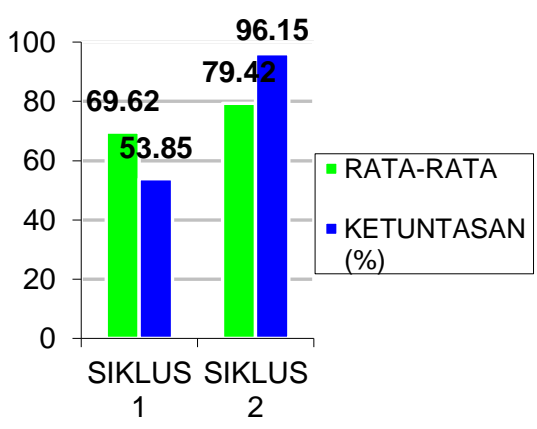


Dari hasil analisis dan semakin meningkat dari siklus ke observasi, adanya peningkatan pada siklus. Hal ini menunjukkan adanya setiap siklus. Dapat disimpulkan pengaruh positif antara peningkatan bahwaada peningkatan kemampuan minat dan sikap dan kerja sama menjelaskan pentingnya pembelaan terhadap nilai ulangan siswa. negara melalui pembelajaran Friend Giving siswa kelas IX A SMP Negeri 1 Wonoasri Madiun tahun pelajaran 2014/2015.

\section{KESIMPULAN}

Berdasarkan pembahasan di atas, dapat disimpulkan bahwa metode pembelajaran friend giving menjadikan siswa lebih aktif dan meningkatkan minat, sikap serta kerja sama siswa dalam proses pembelajaran khususnya dalam memahami materi mata pelajaran PKn pada kompetensi dasar menjelaskan pentingnya pembelaan negara.

Dengan penggunaan metode friend giving memberikan suasana yang menyenangkan bagi siswa. Hal ini terlihat dari antusias siswa dalam mengikuti proses pembelajaran. Dengan keaktifan siswa dan suasana yang menyenangkan saat pembelajaran PKn pada kompetensi dasar menjelaskan pentingnya pembelaan negara, hasil belajar/ tes 
DAFTAR PUSTAKA

Depdikbud. 1999. Bahan Pelatihan Penelitian Tindakan (Action Research). Jakarta: Dirjen Dikdasmen dan Dikmenum.

Departemen Pendidikan Nasional Kurikulum 2006. Pedoman Khusus Pengembangan Silabus dan Penilaian Pendidikan

Kewarganegaraan.

E. Mulyasa. 2005. Menjadi Guru Profesional, Bandung: PT Remaja Rosdakarya.

Endah TriPriyatni. 2002. Konsep dan Penerapan Penelitian Tindakan Kelas. Malang: UM.

Hamalik, O. 2001.Proses Belajar Mengajar.Jakarta: PT. Bumi Aksara.

Kusaeri. 2001. Pembelajaran Aktif, Reflektif dan Gaya Belajar. Yogyakarta: PT. Gavamedia.

Nurhadi. 2002. Metode Pembelajaran Efektif.Bandung : P.T Tarsito.

Suharsimi Arikunto. 1997. Prosedur Penelitian. Jakarta : Bina Aksara

Tabrani Rusyan Atang Kuswidja. 1989, Pendekatan dalam Proses Belajar Mengajar. Bandung: CV Remadja Karya.

Usman. 2002. Proses Belajar Mengajar . Jakarta: Prestasi Pustaka Raya.
Winkel W.S. 1998. Psikologi Pengajaran. Yogyakarta: Gramedia. 